\title{
ARTIFICIAL INTELLIGENCE-BASED DEVELOPMENT STRATEGY IN DEPENDENT MARKET ECONOMIES - ANY ROOM AMIDST BIG POWER RIVALRY?
}

\section{Szalavetz, A.}

Andrea Szalavetz / Centre for Economic and Regional Studies - Institute of World Economics, 1097 Budapest, Tóth Kálmán str. 4, Hungary. Email: aszalave@gmail.com

\begin{abstract}
This paper investigates whether the activities of start-ups specialising in artificial intelligence (Al)-powered solutions could contribute to upgrading in dependent market economies. Mapping the ecosystem of Hungarian Al-solution providers, collecting, and analysing data of their solutions, activities, and performance, we identify the main mechanisms of $\mathrm{Al}$-driven upgrading. We argue that Al-solution providers induce productivity and resource efficiency improvement at technology adopters by enabling process upgrading. By selling their services to the local subsidiaries of global companies, they intensify the local backward linkages of these companies. Increased local embeddedness of subsidiaries is an important manifestation of economic upgrading. Additionally, Alsolution providers diversify the drivers of growth. In dependent market economies, where export-oriented manufacturing activities controlled by efficiency-seeking foreign investors used to be the main (unique) growth engine, the activities of domestic-owned Al solution providers represent a new driver of growth: technology-oriented entrepreneurship. We found, however, that the economic impact of Hungarian Al-oriented ventures is limited, no matter how innovative their solutions are. Managerial implications include the indispensability of devising an adequate business development strategy and a value capture strategy. Without adequate entrepreneurial skills, and without being visible on the global stage of 'Al-start-ups to watch', the development prospects of even the most innovative ventures are limited. A key policy implication for supporting the scaling up of $\mathrm{Al}$ start-ups by promoting the adoption of $\mathrm{Al}$-powered solutions and stimulating venture capital financing promises good return on public investments.
\end{abstract}

Keywords: artificial intelligence, start-ups, upgrading, Hungary

JEL Classification: M13, O33

\section{Introduction}

For observers relating global power transitions to changes in techno-economic paradigms, the rapid development and ubiquitous diffusion of artificial intelligence represents a strategic opportunity to catch up and/or forge ahead. 
Artificial intelligence $(\mathrm{Al})$ is defined as a system, composed of hardware and software, that is capable of processing, synthesising, and learning from big data and information from various sources in order to perform (automate or support) tasks that used to be performed only by humans. Al is considered the paradigm-leading, general purpose technology of the "Second Machine Age" (Brynjolffson \& McAfee, 2014). It will revolutionise many areas of economic activity and induce complementary innovations with a transformative impact on economy and society.

From a historical perspective, the emergence of new paradigm-leading technologies generate changes in the balance of economic power (Horowitz et al., 2018; Perez, 2002). It is by no surprise that while the current Al superpowers (the United States and China) announce strategic plans aimed at achieving global leadership in Al, many other advanced and emerging economies also develop Al strategies, aimed at Al-based upgrading and catch-up (e.g. COMM, 2018; Horowitz et al., 2018; Lee, 2018). ${ }^{1}$

Considering the magnitude of Al superpowers' efforts and the fact that strong first-mover advantages are expected to be obtained in an 'Al race for strategic advantage' (Cave \& ÓhÉigertaigh, 2018), this paper investigates the chances of an Al-based development in dependent market economies (DMEs), whose modernisation has, so far, been driven by efficiency-seeking foreign direct investment (Nölke \& Vliegenthart, 2009).

The question in the case of these countries is not whether specialisation in Al-associated technology provision could induce a kind of leapfrog development - as is happening in China. The opportunity to be considered for these countries is rather that of mitigating their current excessive reliance on 'low-cost manufacturing location'-based integration in global value chains (GVCs). Since Al-powered labour-saving technologies will particularly adversely affect jobs in activities that had been offshored to DMEs with a resource/efficiency-seeking motivation, upgrading by diversifying the drivers of growth seems indispensable.

However, upgrading through Al-based innovation and entrepreneurship in DMEs is contingent on negative answers to two questions. Is Al a developed country issue? Is Albased competition confined to large and powerful economic actors?

Intuition suggests an affirmative answer to both these questions. On one hand, digital technologies, network externalities, and globalisation enhance the concentration of industries and markets (Bajgar et al., 2018). Furthermore, there is a widely noted development towards winner-take-all structures: 'superstar firms' tend to capture increasing share of total income and profit across a variety of industries, in particular, in service industries featuring a higher-than-the-average level of digital technology adoption (Manyika et al., 2018; Van Reenen, 2018). On the other hand, building Al capabilities in terms of recruiting and paying $\mathrm{Al}$-talent, and investing in expensive computing resources to train machines involve huge costs. This can be afforded only by well-capitalised or generously funded firms.

1 See also: https://medium.com/politics-ai/an-overview-of-national-ai-strategies-2a70ec6edfd for an international overview. 
By contrast, this paper argues that even small DMEs can benefit from fostering specialisation in Al-associated activities, since this strategy can mitigate the looming negative impacts of Al-powered job automation.

The context of the study is Hungary, a DME, whose modernisation and growth have so far been driven by efficiency-seeking foreign direct investment (FDI) inflows in manufacturing (Farkas, 2011). Hungary was selected mainly because of the author's familiarity with the ecosystem of digital technology providers in this country. We survey a sample of domestically-owned companies specialising in Al-associated activities, whose cases are used to illustrate the mechanisms of Al-driven upgrading.

By mapping the Hungarian Al ecosystem and gathering both primary and secondary data on $\mathrm{Al}$ technology providers, we show that specialisation in $\mathrm{Al}$-associated activities can induce new kinds of upgrading mechanisms that diversify and complement the FDI-based upgrading trajectories in DMEs.

Since Hungary is a low/moderate performing country in terms of both innovation (European Innovation Scoreboard, 2018) and business digitalisation performance, ${ }^{2}$ the experiences of the surveyed companies cannot be generalised into optimistic macroeconomic conclusions. Nevertheless, the insights derived from the analysis of their activities offer useful policy lessons and have some thought-provoking managerial implications.

Accordingly, the contribution of this paper is twofold. First it extends our understanding of the mechanisms of Al-driven upgrading through illustrative examples and business use cases. Second, it offers empirical evidence covering an under-researched country case.

The paper proceeds as follows. It starts with a short review of the related literature and focuses on the main mechanisms of Al-driven upgrading. This is followed by the presentation of the research method. Next, we present and discuss the results, provide some concluding remarks, and elaborate on managerial and policy implications.

\section{Theoretical background}

$\mathrm{Al}$ is a solution combining software and hardware elements. This solution ingests and processes data and information from multiple sources so as to perform and automate tasks that were previously only performed by humans (Taddy, 2019). Al and related machine learning are considered general purpose technologies. They are bound to penetrate in and transform all sectors of the economy, disrupt existing and create new industries and services, accelerate and intensify all kinds of innovation activities, and have a transformative impact also on a variety of social processes (Brynjolfsson et al., 2018, Chui, 2019).

However, radical technological change often exacerbates inequality - not only within (cf. the literature on widening wage gaps and labour market polarisation, e.g. Goos et al., 2014) but also across countries (Bajgar et al., 2018; Comin \& Mestieri, 2018). The extra wealth (to be) created by $\mathrm{Al}$ is likely to be shared unequally across countries (Hallward-Driemayer \& Nayyar, 2017), which requires doubling policy efforts to enhance the impact of $\mathrm{Al}$ on upgrading at all levels.

2 Regarding the business digitalisation pillar of the composite Digital Economy and Society Index, Hungary scores the second lowest in EU28, preceding only Romania (DESI, 2018). 
The notion of upgrading is widely used in GVC-analyses (Gereffi \& Fernandez-Stark, 2011) denoting firms' move towards higher-than-before value adding activities as a result of competence accumulation. Upgrading can be manifested in the field of new and highervalue products, improved-efficiency processes, new and higher value generating business functions, or new sectors, markets and business models (Humphrey \& Schmitz, 2002).

Upgrading is frequently discussed also in a macroeconomic context. The economic upgrading of countries is driven by the upgrading of a large, above-a-threshold number of firms that manage to increase the value added nature of their activities (e.g. OECD, 2013; Kummritz et al., 2017). Nevertheless, interpreting economic upgrading as a simple aggregation of firm-level upgrading risks ignoring some developments that also represent qualitative improvement of national performance. When analysing the mechanisms of Aldriven upgrading, our discussion will, therefore, not be limited to Humphrey and Schmitz's (2002) firm-level upgrading categories; other macro-level developments will also be considered.

Technological change in general, and Al in particular, can drive upgrading by four mechanisms, as follows. One is process upgrading enabled by the adoption of Al-powered solutions, resulting in the improvement of productivity and of operational excellence.

Another mechanism is functional upgrading, which refers here to companies complementing their primary (production) activities with Al-associated R\&D. Taking up knowledge-intensive, usually software development related activities and business functions is indispensable for the adoption and use of Al.

Manufacturing and practically all other business processes and functions are characterised by high and increasing software-intensity which reinforces the globalisation of R\&D (Branstetter et al., 2019). Consequently, even the manufacturing subsidiaries of multinational corporations (MNCs) often take up Al-specific R\&D and/or become engaged in Al-supported product development, at least more often than previously. Additionally, the adoption of Al-powered solutions is usually accompanied by organisational and technological learning, capability development, and an increased demand for and employment of highly skilled workers (see Burger et al. (2018) on functional upgrading in Central and Eastern European countries).

The third mechanism is upgrading through the intensification of MNC subsidiaries' local backward linkages. Al-solutions are not off-the-shelf ones: they address customer-specific business cases. Consequently, their deployment requires significant domain-specific expertise (to understand customers' business processes and determine the key performance indicators to be improved). This expertise is developed through a series of interactions between the technology providers and the would-be users (Taddy, 2019), which calls for selecting local technology providers.

This latter mechanism is closely associated with the fourth channel of Al-driven economic upgrading, that of local actors' innovation-based entrepreneurship, internationalisation, and rapid growth. Worldwide, digital transformation and specialisation in the provision of $\mathrm{Al}$ powered solutions have boosted new forms of innovation, multiplied the number, and accelerated the evolution of entrepreneurial ventures (Nambisan, 2017). This is reflected by 
a rising number of unicorns, ${ }^{3}$ start-ups valued at $\$ 1$ billion or more. Although most of them are from the United States and China, some dependent economy actors, such as Indonesia, Philippines, or Estonia are also present in this list. Nevertheless, from the perspective of economic growth through Schumpeterian entrepreneurship (cf. Lafuente et al., 2019), it is not the achievement of the predetermined threshold of $\$ 1$ billion that matters, particularly not in the surveyed DMEs, but, rather, the highest possible number of technology-oriented (in our case: Al-oriented), rapidly growing and internationalising startups.

\section{Research method}

The research method adopted for this study is a combination of desk research and interview-based research. Desk research was aimed at mapping Hungarian, domesticallyowned companies that develop core Al technologies, or integrate Al technologies into their products or product-service solutions. This exploratory exercise combined a survey of business press and technology press articles ${ }^{4}$ describing, among others, the Al-related activities and achievements of Hungarian companies, and a review of secondary source data on members of two Hungarian associations: the Industry 4.0 National Technology Platform and the (Hungarian) Artificial Intelligence Coalition. ${ }^{5}$

Additionally, the author's participation in an Al-related workshop in 2019, where Hungarian start-ups presented their solutions also provided invaluable insights about the activities and performance of Hungarian entrepreneurial ventures specialised in Al-associated technology provision.

This exploratory data collection yielded a sample of 29 Hungarian companies producing Altechnology and Al-enabled solutions (Table 1). We focused on domestically owned ventures and excluded the ones that had been taken over by foreign companies. Foreignowned subsidiaries engaged in Al-related research were also excluded.

Table 1 | Summary 2018 data of the surveyed companies (turnover is in $€$ ' 000 ).

\begin{tabular}{|c|c|l|c|c|}
\hline No. & $\begin{array}{l}\text { Foun- } \\
\text { dation }\end{array}$ & \multicolumn{1}{|c|}{ Profile } & $\begin{array}{c}\text { Turnover } \\
\text { (Target } \\
\text { market) }\end{array}$ & $\begin{array}{c}\text { Employ- } \\
\text { ment }\end{array}$ \\
\hline 1. & 2007 & $\begin{array}{l}\text { Development of an autonomous decision support } \\
\text { system for optimisation of logistics planning; a } \\
\text { maintenance scheduling system, and a diagnostics } \\
\text { management system (for a biopharmaceutical } \\
\text { company). }\end{array}$ & $\begin{array}{c}3,943 \\
\text { (D) }\end{array}$ & 12 \\
\hline 2. & 2017 & $\begin{array}{l}\text { Development of an industrial Internet of Things (IloT) } \\
\text { platform that is based on big data technologies and } \\
\text { machine learning. The platform supports smart }\end{array}$ & $\begin{array}{c}25 \\
\text { (D) }\end{array}$ & 10 \\
\hline
\end{tabular}

\footnotetext{
${ }^{3}$ According to the regularly updated unicorn list of $C B$ Insights, the number of unicorns in mid-2019 was 350. https://www. cbinsights.com/research-unicorn-companies, retrieved on: 20, May, 2019.

4 The articles have been collected from a variety of sources, including www.techmonitor.hu, and www.gyartastrend.hu, both offering a collection of articles on industrial applications of new technology, and case studies of Hungarian and international actors developing particular digital solutions. Additionally, the websites www.computerworld.hu, www.hwsw.hu, and www.itbusiness.hu have also proved useful sources of information about Hungary-based Al-associated companies.

${ }_{5}$ In May, 2019, Al Coalition had 178 members. Approximately one third of the members were business enterprises engaged in Al-related activities, while other members included NGOs, e.g. professional and industry associations, and governmental organisations, consultancy firms, and higher education institutions.
} 


\begin{tabular}{|c|c|c|c|c|}
\hline & & $\begin{array}{l}\text { factory applications, such as predictive maintenance, } \\
\text { and is capable of implementing machine-learning- } \\
\text { powered process optimisation. }\end{array}$ & & \\
\hline 3. & 2016 & $\begin{array}{l}\text { A solution designed for continuous water monitoring, } \\
\text { automatic detection and Al-aided classification of } \\
\text { organisms in water. The system is capable of } \\
\text { alerting in case of anomalies. }\end{array}$ & $\begin{array}{c}40 \\
(D \& E)\end{array}$ & 5 \\
\hline 4. & 2013 & $\begin{array}{l}\text { Al-powered modelling of cell responses to cancer } \\
\text { treatment at molecular level, running simulated } \\
\text { experiments to identify new biomarkers and } \\
\text { combination therapies in drug development. }\end{array}$ & $\begin{array}{c}284 \\
(\mathrm{E})\end{array}$ & 28 \\
\hline 5. & 2013 & $\begin{array}{l}\text { A solution recognising, converting and transcribing } \\
\text { voice to text, specialised in legal terminology. }\end{array}$ & $\begin{array}{l}152 \\
(\mathrm{D})\end{array}$ & 1 \\
\hline 6. & 2017 & $\begin{array}{l}\text { An Al-powered video analytics solution applied, } \\
\text { among others, in retail to learn shoppers' patterns. It } \\
\text { predicts and reduces queues, traces people, and } \\
\text { detects anomalies. }\end{array}$ & $\begin{array}{c}10 \\
(D \& E)\end{array}$ & 35 \\
\hline 7. & 2018 & $\begin{array}{l}\text { Al projects for telecom network surveillance and } \\
\text { anomaly detection. }\end{array}$ & n.a. & 1 \\
\hline 8. & 2010 & $\begin{array}{l}\text { Provision of data analytics and business intelligence } \\
\text { solutions. }\end{array}$ & $\begin{array}{l}179 \\
\text { (D) }\end{array}$ & 0 \\
\hline 9. & 2018 & $\begin{array}{l}\text { Provision of a warehouse inventory management } \\
\text { solution that combines commercial drones and Al- } \\
\text { based analytics. }\end{array}$ & $\begin{array}{l}7 \\
(\mathrm{D})\end{array}$ & 1 \\
\hline 10. & 2009 & $\begin{array}{l}\text { An Al-powered solution for web-shops, supporting } \\
\text { visitors and providing personalised } \\
\text { recommendations. }\end{array}$ & $\begin{array}{c}183 \\
(D \& E)\end{array}$ & 3 \\
\hline 11. & 1994 & $\begin{array}{l}\text { An integrated risk management and a credit } \\
\text { approval system for financial institutions. }\end{array}$ & $\begin{array}{c}847 \\
(D \& E)\end{array}$ & 23 \\
\hline 12. & 2014 & $\begin{array}{l}\text { An integrated digital ergonomics system: a motion } \\
\text { digitising and evaluating device that captures, } \\
\text { measures, records, and analyses data related to } \\
\text { assembly workers' motion to be used for ergonomic } \\
\text { analyses and testing. }\end{array}$ & $\begin{array}{l}7 \\
(\mathrm{E})\end{array}$ & 4 \\
\hline 13. & 2015 & $\begin{array}{l}\text { Development of a self-driving software stack; } \\
\text { Development of a simulation solution for testing } \\
\text { autonomous vehicles. }\end{array}$ & $\begin{array}{l}5,000^{*} \\
(\mathrm{E})\end{array}$ & 182 \\
\hline 14. & 2012 & $\begin{array}{l}\text { Development of connected vehicle technology to be } \\
\text { integrated in on-board units or roadside units. }\end{array}$ & $\begin{array}{l}1,000^{*} \\
(\mathrm{E})\end{array}$ & 30 \\
\hline 15. & 2013 & $\begin{array}{l}\text { Design and implementation of smart factory } \\
\text { solutions coupled with analytics for manufacturing } \\
\text { companies. Data-driven and Al-powered business } \\
\text { process reengineering and optimisation, solution of } \\
\text { technological problems. Implementation of machine } \\
\text { learning solutions to support autonomous decision- } \\
\text { making. }\end{array}$ & $\begin{array}{l}67 \\
(\mathrm{D})\end{array}$ & 2 \\
\hline 16. & 2012 & $\begin{array}{l}\text { Provision of data analytics, data warehousing, and } \\
\text { business intelligence solutions. }\end{array}$ & $\begin{array}{l}1,700^{*} \\
(\mathrm{D})\end{array}$ & 14 \\
\hline 17. & 2006 & $\begin{array}{l}\text { Provision of big data, data visualisation, and } \\
\text { analytics-based solution of company-specific } \\
\text { problems; data engineering, data warehousing, } \\
\text { cloud data services, data integration, and strategic } \\
\text { consulting relying on data science approaches. }\end{array}$ & $\begin{array}{l}9,400^{*} \\
(E)\end{array}$ & 136 \\
\hline 18. & 2014 & $\begin{array}{l}\text { Automation of customer relationship management } \\
\text { through Al bots. }\end{array}$ & $\begin{array}{l}24 \\
(\mathrm{E})\end{array}$ & 5 \\
\hline 19. & 2015 & $\begin{array}{l}\text { Development of a solution to prevent fraud with } \\
\text { online advertising by detecting robots and suspicious } \\
\text { traffic, and then measuring the real visibility of } \\
\text { advertisements. }\end{array}$ & $\begin{array}{c}244 \\
(D \& E)\end{array}$ & 5 \\
\hline
\end{tabular}




\begin{tabular}{|c|c|c|c|c|}
\hline 20. & 2004 & $\begin{array}{l}\text { Development of a human speech processing } \\
\text { solution to be applied in virtual customer service } \\
\text { assistants; assists customers with self-service or } \\
\text { channels them to the appropriate customer service } \\
\text { operator. Provision of business intelligence services. }\end{array}$ & $\begin{array}{l}1,074 \\
\text { (D) }\end{array}$ & 12 \\
\hline 21. & 2004 & $\begin{array}{l}\text { A variety of smart solutions, including road condition } \\
\text { mapping, security solutions based on computer } \\
\text { vision and video analysis, traffic monitoring and } \\
\text { analysis, social network analysis, voice call analysis, } \\
\text { sign language translation, etc. }\end{array}$ & $\begin{array}{l}556 \\
(D \& E)\end{array}$ & 13 \\
\hline 22. & 2017 & $\begin{array}{l}\text { Development of a smart insurance (pay as you drive) } \\
\text { application based on vehicle telematics and big data. }\end{array}$ & $\begin{array}{l}1.8 \\
(E)\end{array}$ & 2 \\
\hline 23. & 2016 & $\begin{array}{l}\text { Enterprise chatbot development, system integration, } \\
\text { bot data analysis, marketing automation services. }\end{array}$ & $\begin{array}{l}550 \\
(\mathrm{E})\end{array}$ & 4 \\
\hline 24. & 2011 & $\begin{array}{l}\text { Al-powered personalisation solutions } \\
\begin{array}{l}\text { product recommendations, earch, } \\
\text { couponing, video services etc.) }\end{array}\end{array}$ & $\begin{array}{l}3,440^{*} \\
(E)\end{array}$ & 34 \\
\hline 25. & 2018 & $\begin{array}{l}\text { Al-powered robotic task automation, e.g. invoice } \\
\text { processing, machine vision-based quality control, } \\
\text { predictive maintenance, demand prediction. }\end{array}$ & $\begin{array}{l}\text { n.a. } \\
(\mathrm{D} \& \mathrm{E})\end{array}$ & 12 \\
\hline 26. & 2008 & $\begin{array}{l}\text { Development of an intelligent search and data } \\
\text { collection engine; a text analytics solution (e.g. } \\
\text { medical texts); provision of software development, } \\
\text { system integration, and business intelligence } \\
\text { services. }\end{array}$ & $\begin{array}{c}420 \\
(D \& E)\end{array}$ & 28 \\
\hline 27. & 2012 & $\begin{array}{l}\text { Development of a customer loyalty management } \\
\text { platform that drives omnichannel customer } \\
\text { engagement through programmes, personalisation, } \\
\text { customer profiling, and business intelligence. }\end{array}$ & $\begin{array}{c}674 \\
(\mathrm{E})\end{array}$ & 20 \\
\hline 28. & 2015 & Al-powered translation technology. & $\begin{array}{c}5,000 \\
(\mathrm{E})\end{array}$ & 47 \\
\hline 29. & 2012 & $\begin{array}{l}\text { Development of a social listening and business } \\
\text { intelligence tool that provides a real-time quantitative } \\
\text { and qualitative analysis of social media and other } \\
\text { Internet content, e.g. with respect to selected } \\
\text { companies, brands, etc. It measures the efficiency of } \\
\text { social media marketing and the evolution of public } \\
\text { perception of the given company/brand. }\end{array}$ & $\begin{array}{l}242 \\
(D \& E)\end{array}$ & 3 \\
\hline
\end{tabular}

${ }^{*}=$ rounded, $\mathrm{E}$ = mainly export sales, $\mathrm{D}=$ mainly domestic sales

Source: author's compilation

We reviewed the websites of the companies in the sample and collected press articles describing their activities and achievements. Next, we collected data about the basic corporate performance indicators (year of establishment, turnover, employment) and about the specifics of the technology developed by these companies. Additionally, we reviewed their references, i.e. the list of their major customers and the use cases that were described on their websites or in business press articles. We complemented our secondary-source data with information obtained from the presentations of their representatives at the workshop mentioned previously and with data obtained from interviews conducted with five companies in this sample. These interviews were conducted during February-March 2019 in the framework of a separate research project on digital entrepreneurship in Hungary. ${ }^{6}$

${ }^{6}$ Twelve Hungarian digital entrepreneurs were interviewed in the framework of that research project. Five of them are engaged in Al-associated activities. Since the interview guide we used coincides with the focus of this research (it consisted of open-ended question organised around three topics: the 
Our data analysis consisted of two components. Sample firms' data were coded according to categories related to their profile (Al-associated activities and use cases) and business performance. This coding exercise was complemented with the qualitative analysis of the firms' impact on economic upgrading, along the theoretical categories outlined in the previous section.

The reliability and validity of our findings was ensured through cross-case comparisons. Additionally, we tested our arguments developed on the basis of the analysis of the surveyed firms' data by asking the managers interviewed to comment on them. The draft version of the paper was sent to all interviewees for feedback.

\section{Findings}

Our mapping exercise helped us identify a diverse set of Hungarian firms engaged in Alpowered solution development or in the development of core AI technology. The basic data of the surveyed start-ups (establishment, number of employees, revenues) revealed that most of them are young, ${ }^{7}$ micro or small companies, both in terms of employment and revenues. There were only two firms with more than 50 employees, and the turnover of 21 firms out of 29 was below EUR 1 million in 2018.

The surveyed firms are all vertically focussed: their transactions are of a business-tobusiness (B2B) type. They target various industries, and support or automate numerous business functions. Accordingly, their customer base is highly heterogeneous. ${ }^{8}$ Nine companies in the sample target mainly the domestic market, eleven firms are mainly exportoriented, and in the case of the rest, domestic and foreign customers account for a more or less balanced share of the revenues. Since the adoption of Al technologies requires a relatively high degree of technology readiness by users, their key customers - both the domestic and the foreign ones - are usually large and powerful organizations, often global 'blue chip' companies or their local subsidiaries (Table 2).

history of the venture, the specifics of product and market development, and the specifics of the venture's ecosystem) we could use the interview results of these five companies to complement the secondary-source information collected in the course of this research project.

716 firms were founded after 2012. On average, sample companies have been operating for 6 years in 2019.

${ }^{8}$ Some firms have currently only one single or a couple of powerful customers, while others have dozens of corporate users of their solutions. 
Table 2 Some of the key customers of the surveyed firms*

\begin{tabular}{|l|l|}
\hline \multicolumn{1}{|c|}{ Al solutions, applications, algorithms' } & \multicolumn{1}{|c|}{ Examples of customers } \\
\hline $\begin{array}{l}\text { Enterprise solutions (business intelligence, } \\
\text { analytics) }\end{array}$ & $\begin{array}{l}\text { Fortune } 500 \text { companies: e.g. Apple, Tesla, } \\
\text { Facebook, Netflix, Honeywell, ABB } \\
\text { Hungarian and foreign companies and } \\
\text { governmental organisations: Renault, National } \\
\text { Tax and Customs Administration, Vodafone, DB } \\
\text { Schenker, CIB Bank, MOL }\end{array}$ \\
\hline $\begin{array}{l}\text { Al solutions supporting or automating } \\
\text { business functions such as marketing, HR, } \\
\text { customer services, inventory management, } \\
\text { risk management, ergonomics, R\&D }\end{array}$ & $\begin{array}{l}\text { Large Hungarian or foreign banks, public utility } \\
\text { companies, insurance companies, } \\
\text { telecommunication providers, } \\
\text { webshops, retail companies, manufacturing } \\
\text { companies: e.g. OTP, Vodafone, Telenor, } \\
\text { Allianz, Aegon, E-On, IKEA, Auchan, Decathlon, } \\
\text { Audi, Bayer }\end{array}$ \\
\hline $\begin{array}{l}\text { Al solutions powering operations, e.g. in } \\
\text { manufacturing and logistics (resource } \\
\text { optimization, predictive maintenance, } \\
\text { anomaly detection) }\end{array}$ & $\begin{array}{l}\text { EGIS, Mercedes Benz Manufacturing, Audi } \\
\text { Hungaria, Magna Automotive, Waberer, MOL }\end{array}$ \\
\hline Al solutions supporting compliance & $\begin{array}{l}\text { Hungarian food industry firms, public utilities, } \\
\text { banks }\end{array}$ \\
\hline $\begin{array}{l}\text { Al solutions supporting cyber security, } \\
\text { surveillance, and fraud prevention }\end{array}$ & $\begin{array}{l}\text { Media companies \& other diverse users: T- } \\
\text { Mobile, Sanoma Media, Saturn, Danone, Erste } \\
\text { Bank, municipalities, department stores }\end{array}$ \\
\hline $\begin{array}{l}\text { Collaboration in research, sales and } \\
\text { demonstration projects with Ford, Jaguar, Alps } \\
\text { autonomous vehicle technologies, industrial } \\
\text { Internet of Things Platform }\end{array}$ & $\begin{array}{l}\text { Electric Co., Qualcomm, NXP, Autotalks, Groupe } \\
\text { PSA, Global Foundries, Kyocera, Volvo, Nvidia, } \\
\text { Samsung, municipalities in U.S., UK, France, } \\
\text { collaboration with Cloudera, Dell }\end{array}$ \\
\hline
\end{tabular}

Notes: * The table is not intended to be exhaustive; each solution integrates several companies Source: author's compilation.

The heterogeneity of both the application fields and the customers reflects the generalpurpose character of Al. At the same time this impeded the unambiguous classification and grouping of the surveyed firms. We intended to cluster the firms in terms of the kinds of upgrading induced by their activities, e.g. process upgrading and productivity improvement, technology-oriented entrepreneurship, multiplication of MNC subsidiaries' backward linkages. ${ }^{9}$ We found that the majority of the surveyed solutions applies to each of these categories.

For instance, Al-powered robotic process automation solutions developed by the surveyed domestic entrepreneurs enhance the productivity of technology adopting firms. Consequently, in these cases the first channel of Al-driven upgrading is relevant. Since the given firms are domestically-owned entrepreneurs, the fourth channel also applies to their case. However, the analysis of the customer base of these firms revealed that some customers were MNCs' local subsidiaries. Accordingly, the third channel, the intensification of MNCs' local backward linkages is also relevant. And finally, since the integration of Alpowered solutions in technology adopting firms' business processes required the

${ }^{9}$ Since our sample consists of Hungarian start-ups, this study investigates only three of the four mechanisms of Al-driven upgrading discussed in the previous section. Al adoption-driven functional upgrading at local manufacturing subsidiaries is not discussed. 
collaboration of adopting firms' engineers, whose expertise was indispensable for the customisation of the given solutions, technology adoption was accompanied by the functional upgrading of MNCs' local subsidiaries (second channel).

As a result, instead of using a discretionary method to group the sample companies according to the upgrading categories they represent, we first analysed the scope of process upgrading. Our data analysis suggests that the solutions developed by the surveyed companies automate or support very specific parts of users' complex value generation processes. Some of the solutions automate or support activities, the productivity of which was previously not even measured at technology adopters. Examples include enterprise chatbot development for customer engagement and marketing purposes; deployment of a platform for Al-powered internal communication (between the management and blue-collar workers) and workflow management. One company developed a system to improve the productivity of cancer drug discovery, i.e. the productivity of finding effective combinations through Al-powered modelling how cancer works at the molecular level, and simulating millions of combinations. Again, the scope of productivity improvement is hard to measure in this case, since it can be evaluated only ex-post, if an effective combination is found, by comparing the speed and costs of this method with those of a traditional trial and error approach.

In other cases, productivity and resource efficiency improvement were easy to calculate. For example, a warehouse inventory management solution (No. 9) replaced, on average, two full time employees after adopting the technology. The number of employees replaced (or working time saved) by Al-powered solutions was easy to calculate also in other use cases, for example, in the case of automation of invoice processing ${ }^{10}$ or water quality monitoring, automatic transcription of speech into text, or in cases when Al-powered translation solutions were applied. It needs to be noted though that substitution of human work for capital does not necessarily lead to reduction in headcount: employees replaced in one activity often move to perform new tasks in the same company. In any case, adopters' productivity is bound to improve as a consequence. Since Al-powered task automation eliminated the least interesting, repetitive activities, the reallocation of workers to other, more ambitious activities, accompanied by relevant training, leads to the upgrading of work.

An easy-to-quantify example of the impact of Al on resource efficiency was observed at an automotive seats manufacturer. The Al-powered automation of quality control was found to reduce the loss of raw material by $63 \%$.

In other cases, the deployment of an Al-powered solution for predictive maintenance reduced unplanned downtime, scrap, and maintenance costs, and increased the mean time between machine failures. The optimisation of route planning for a truck fleet operator increased average truck usage from $87 \%$ to $92 \%$.

The extent of process upgrading-related productivity or resource efficiency improvement can be considered marginal in some of these cases, since they are manifested in narrow areas of adopters' complex business processes. Moreover, technology adopters have been devoting efforts to improve the given performance indicators (efficiency of inventory

10 This refers to the digitalisation of paper-based invoices so as to integrate them in the enterprise resource planning system. Al was trained to recognise, interpret and process invoices in various formats. 
management, unplanned downtime, scrap, fleet asset utilisation rate, etc.) for decades. Consequently, these indicators had already reflected very good performance even before technology adopters invested in new, Al-powered solutions and the scope for further improvement was limited.

Nevertheless, the indicator considered by the customers of the surveyed firms is not the extent of productivity or resource efficiency improvement to be achieved through the deployment of the given solution. Customers are rather concerned with return on investment $(\mathrm{ROI})$, which allowed the companies in our sample to team up with and gain business opportunities from MNCs' local subsidiaries or from large foreign companies.

Next, we analysed the economic impact of the surveyed entrepreneurial ventures in terms of the entrepreneurial outcome of their activities.

In line with the fact that sample companies supply valuable, rare, inimitable, and nonsubstitutable (VRIN) solutions (Barney, 1991), part of them have been highly successful in acquiring and retaining large, powerful, domestic or foreign-owned customers (including Fortune 500 companies). However, the business performance of at least half of the surveyed companies, as measured by the usual indicators of sales and employment, seems meagre, at least if compared to what the international success stories of Al start-ups suggest. ${ }^{11}$ The turnover of half ${ }^{12}$ of the firms in the sample (13 companies) was below EUR 250,000 (the turnover of eight companies was below EUR 100,000). The average turnover was EUR 1.3 million across the sample $(n=27)$ in 2018 , but that of the low-growth half of the sample was only EUR 91,000. The average number of employees was 23.2, however, without the two large outlier companies, this average was only 13.1. Consequently, it seems safe to maintain that half of the surveyed firms remained (so far) exposed to the common growth constraints faced by DME firms, however innovative their solutions are.

\section{Discussion, conclusion and implications}

The focus of this article was on the ways the Al applications developed by the surveyed companies contribute to upgrading. The results make us conclude that despite the innovativeness of sample firms' solutions and irrespective of the fact that their activities have an unambiguously positive impact on upgrading, these cases are not sufficiently robust for shifting Hungary to an innovation-driven growth trajectory, or for enabling the country's escaping from the trap of dependence on low-local-value-added, export-oriented manufacturing activities established by efficiency-seeking FDI.

Although our mapping of domestic-owned entrepreneurs engaged in Al-related research and development is by no means exhaustive, it can be plausibly claimed that the number of Hungarian Al-oriented digital entrepreneurs is statistically insignificant. Additionally, the sales performance of only a few of the surveyed highly innovative digital entrepreneurs exceeds EUR one million: in this sense, most of the surveyed firms have remained micro

\footnotetext{
${ }^{11}$ Note that most business press articles and international databases on Al start-ups report data only on the valuation and the funding of the given companies. By contrast, company-level data on revenues or employment are scarce. Anecdotal evidence indicates that most Al start-ups find it hard to generate adequate revenues to build business: often they are valued far more highly than what their revenue performance would suggest (Basta, 2016).

12 We had exact turnover data only for 27 firms.
} 
enterprises. Except for a couple of companies, the sample firms failed to become important job creators.

One of the thought-provoking findings was that the business performance of the surveyed firms was apparently weakly related to their export orientation. There were several exportoriented companies (No. 12, 18, 22) that have, so far, failed to scale up. Conversely, a number of mainly or uniquely domestically-oriented companies were identified whose sales performance was much better than the average (e.g. No. 1, 11, 16, and 20).

The relatively high share of companies targeting mainly the domestic market challenges the assumption that digital entrepreneurs - in particular, the ones specialised in highly innovative, Al-powered services provision - can access global markets relatively easily. The claim that they would pursue the identified opportunities at a geographically less restricted scale than traditional, brick-and-mortar entrepreneurs (Nambisan, 2017) is also called into question.

Altogether, irrespective of the high R\&D-intensity of their activities, which is an important indicator of economic upgrading, the impact of the surveyed firms on the economy has remained, so far, limited.

Nevertheless, it can be concluded that specialisation in Al-associated activities unequivocally contributes to upgrading for three reasons. One is the VRIN-features of the offerings and the knowledge-intensity of Al-associated activities, which suggests a higher average local unit value added than that of manufacturing activities. The second is that, according to our data, part of the surveyed firms' customers are global firms' local manufacturing and service subsidiaries. Consequently, specialisation in Al-associated activities contributes to the intensification of foreign-owned firms' local backward linkages.

Thirdly, the activities of the surveyed firms can definitely diversify the drivers of growth in Hungary and increase the relevance of growth through Schumpeterian entrepreneurship (cf. Lafuente et al., 2019) in DMEs. The meaningfulness (the aggregate economic impact) of this kind of upgrading depends, however, on the number and growth performance of these ventures.

Our results suggest that the main difference between advanced economies and lagging DMEs does not lie in the performance (innovativeness, speed of internationalisation, turnover) of their top Al start-ups: these are more or less comparable. Underperformance can be captured rather in terms of company demographics and performance: DMEs have fewer high-performance start-ups producing Al-solutions. ${ }^{13}$

Highlighting the indispensability of devising an adequate business development strategy, accompanied by a value capture strategy, these results have important managerial implications. They demonstrate that no matter how brilliant the technology is, without

${ }^{13}$ For example, Israel, a dominant player in Al-technology, and a country with a size of population comparable to that of Hungary, was home of more than 1,100 Al companies in 2018 (Korbet, 2019). Roland Berger and France Digitale (2018) have built a database containing information on the Al ecosystem (number and density of start-ups) in 30 European countries (EU28, Norway, and Switzerland). According to the results of their mapping, except for Poland, the number of Al-start-ups was below 50 in all New Member States (NMS), in 2018 (it was over 300 in France and Germany, respectively, and over 800 in the UK). Except for Estonia ( 1.15), start-up density (start-ups per population) was below 0.4 in in NMS (in Hungary: 0.12). 
adequate entrepreneurial skills, and without being visible on the global stage of 'Al-start-ups to watch', the development prospects of even the most innovative ventures are limited.

The surveyed cases also demonstrate the importance of a precise value proposition. For example, when negotiating with would-be customers, companies need to quantify the speed of ROI, in addition to 'advertising' the innovativeness of the technology.

As for the policy implications, our results call for enhancing and diversifying the support system to improve Hungary's ability to exploit the potential of Al for value creation and capture. Launching Al-specific entrepreneurship programmes, setting up incubators and accelerators, increasing the volume of grants to specific stages of Al-research and commercialisation, and supporting the financing of Al start-ups' growth and international expansion through venture capital funds promise good return on public investment. ${ }^{14}$ Furthermore, it is particularly important to support the scaling up of Al start-ups, for example by systematically integrating $\mathrm{Al}$-applications in public services, and by promoting the implementation of Al-powered solutions in the business sector. Issuing innovation vouchers for Al-deployment promises hitting two birds with one stone: in addition to supporting technology-oriented entrepreneurs it also contributes to improving technology adopters' total factor productivity.

\section{Acknowledgement}

Research for this paper was supported by the Pallas Athéné Innovation and Geopolitical Foundation (PAIGEO).

\section{References}

Bajgar, M., Berlingieri, G., Calligaris, S., Criscuolo, C., \& Timmis, J. (2019). Industry Concentration in Europe and North America. OECD Productivity Working Papers, No. 18., Paris: OECD Publishing.

Barney, J. (1991). Firm resources and sustained competitive advantage. Journal of Management, 17(1), 99-120.

Basta, W. (2016). Artificial Intelligence Teams Being Acquired For $\$ 2.5 \mathrm{~m} / \mathrm{employee;} \mathrm{Employee} \mathrm{Value}$ Often Far Exceeds Business Value. https://www.linkedin.com/pulse/artificial-intelligence-teamsbeing-acquired-employee-victor-basta/

Branstetter, L. G., Glennon, B., \& Jensen, J. B. (2019). The IT Revolution and the Globalization of R\&D. Innovation Policy and the Economy, 19(1), 1-37.

Brynjolfsson, E., \& McAfee, A. (2014). The second machine age: Work, progress, and prosperity in a time of brilliant technologies. WW Norton \& Company.

Brynjolfsson, E., Mitchell, T., \& Rock, D. (2018). What Can Machines Learn, and What Does It Mean for Occupations and the Economy? In: AEA Papers and Proceedings, Vol. 108, pp. 43-47.

Bughin, J. (2019). How to develop enough European Al startups. Vox, https://voxeu.org/article/howdevelop-enough-european-ai-startups.

\footnotetext{
${ }^{14}$ Bughin (2019) provides evidence of the importance of start-ups' access to funding. He estimated the general translog function of Al start-up density with the availability of capital (the cumulative amount of deep-tech investment) in a sample of countries and cities. His model confirmed that the elasticity of start-up density linked to financing is more than double the elasticity linked to an otherwise also indispensable production factor: the availability of human capital.
} 
Burger, A., Jindra, B., Marek, P., \& Rojec, M. (2018). Functional upgrading and value capture of multinational subsidiaries. Journal of International Management, 24(2), 108-122.

Cave, S., \& ÓhÉigeartaigh, S. (2018). An Al race for strategic advantage: rhetoric and risks. In: AAAI/ACM Conference on Artificial Intelligence, Ethics and Society. http://www.aiesconference.com/2018/contents/papers/main/AIES_2018_paper_163.pdf

Comin, D., \& Mestieri, M. (2018). If technology has arrived everywhere, why has income diverged? American Economic Journal: Macroeconomics, 10(3), 137-78.

COMM (2018). Communication from the Commission to the European Parliament, the European Council, the Council, the European Economic and Social Committee and the Committee of the Regions on Artificial Intelligence for Europe. https://ec.europa.eu/digital-singlemarket/en/news/communication-artificial-intelligence-europe

Chui, M., Manyika, J., Miremadi, M., Henke, N, Chung, R., Nel, P., \& Malhotra, S. (2018). Notes from the Al frontier: Applications and value of deep learning. McKinsey Global Institute Discussion Paper, April, https://www.mckinsey.com/featured-insights/artificial-intelligence/notes-from-theai-frontier-applications-and-value-of-deep-learning?reload

DESI (2018). Digital Economy and Society Index Report 2018, Integration of Digital Technologies. https://ec.europa.eu/digital-single-market/en/desi

European Innovation Scoreboard (2018). https://ec.europa.eu/docsroom/documents/30684

Farkas, B. (2011). The Central and Eastern European model of capitalism. Post-Communist Economies, 23(1), 15-34.

Gereffi, G., \& Fernandez-Stark, K. (2011). Global value chain analysis: a primer. Center on Globalization, Governance \& Competitiveness (CGGC), Duke University, NC, USA. Available at: http://www.cggc.duke.edu/pdfs/2011-05-31 GVC analysis a primer.pdf

Goos, M., Manning, A., \& Salomons, A. (2014). Explaining job polarization: Routine-biased technological change and offshoring. American Economic Review, 104(8), 2509-26.

Hallward-Driemeier, M., \& Nayyar, G. (2017). Trouble in the Making? The Future of Manufacturing-led Development. Washington: World Bank Publications.

Horowitz, M. C., Allen, G. C., Kania, E. B., \& Scharre, P. (2018). Strategic Competition in an Era of Artificial Intelligence. Washington: CNAS Center for a New American Security.

Humphrey, J., \& Schmitz, H. (2002). How does insertion in global value chains affect upgrading in industrial clusters? Regional Studies, 36(9), 1017-1027.

Korbet, R. (2019). The state of the Israeli ecosystem. 2018. Start-Up Nation Central, Finder Insight Series.

Kummritz, V., Taglioni, D., \& Winkler, D. (2017). Economic upgrading through global value chain participation: which policies increase the value added gains? World Bank Policy Research Working Paper, No. 8007, Washington: the World Bank.

Lafuente, E., Acs, Z. J., Sanders, M., \& Szerb, L. (2019). The global technology frontier: productivity growth and the relevance of Kirznerian and Schumpeterian entrepreneurship. Small Business Economics, in press, https://doi.org/10.1007/s11187-019-00140-1.

Lee, K. F. (2018). Al superpowers: China, Silicon Valley, and the new world order. New York: Houghton Mifflin Harcourt.

Manyika, J., Ramaswamy, S., Bughin, J., Woetzel, J., Birshan, M., \& Nagpal, Z. (2018). Superstars': The dynamics of firms, sectors, and cities leading the global economy. McKinsey Global 
https://smartnet.niua.org/sites/default/files/resources/mgi superstars discussion paper oct 20 18-final.pdf

Nambisan, S. (2017). Digital entrepreneurship: Toward a digital technology perspective of entrepreneurship. Entrepreneurship Theory and Practice, 41(6), 1029-1055.

OECD. Publishing. (2013). Interconnected economies: benefiting from global value chains. Paris: OECD Publishing.

Perez, C. (2002). Technological revolutions and financial capital. Cheltenham: Edward Elgar.

Roland Berger, \& France Digitale (2018). Joining the dots - A map of Europe's Al ecosystem. Available at:

http://www.francedigitale.org/wp-

content/uploads/2018/10/FranceDigitale_RolandBerger_EUAI.pdf

Taddy, M. (2019). The technological elements of artificial intelligence. In: Agrawal, A., Gans, J., \& Goldfarb, A. (Eds.). The Economics of Artificial Intelligence: An Agenda. Chicago: University of Chicago Press, pp. 61-87.

Van Reenen, J. (2018). Increasing differences between firms: market power and the macro-economy. CEP Discussion Paper, No. 1576.

The research paper has been reviewed. | Received: June 13, 2019; Revised: August 1, 2019; Accepted: September 2, 2019; Prepublished online: September 2, 2019; Published: December 17,2019 